УДК 619:614.31:637.12:351.773(477.53)

(C) 2017

Свстаф'єва В. О., доктор ветеринарних наук, професор,

Клименко О. С., кандидат ветеринарних наук,

Мельничук В. В., кандидат ветеринарних наук,

Натягла I. В., аспірант

Полтавська державна аграрна академія

\title{
ЩОДО ПИТАННЯ ЯКОСТІ ТА БЕЗПЕЧНОСТІ МОЛОКА НА ТЕРИТОРІЇ ПОЛТАВСЬКОЇ ОБЛАСТІ
}

\section{Рецензент - доктор ветеринарних наук А. А. Замазій}

У роботі наведено результати аналізу звітної документації щзодо якості та безпечності молока на території Полтавської області. Встановлено, щзо за період 2012-2016 рр. державними лабораторіями здійснено 740190 досліджень проб молока. Водночас за наслідками експертизи виявлено, щчо 8343 зразки продукиії не відповідають показникам, які затверджені у відповідних державних стандартах. Найбільшу кількість неякісного молока виявили державні лабораторії у 2012 роиці - 3327, щуо становить 2,83\% від загальної кількості досліджуваних проб. Основними причинами вибраковки молока були невідповідність за густиною та кислотністю, вмістом та масовою часткою білку $i$ жиру, а також перевищення кількості соматичних клітин.

Ключові слова: молоко, експертиза, лабораторні дослідження, показники якості $i$ безпечності.

Постановка проблеми. Молоко - продукт харчування, який містить усі необхідні для організму людини речовини в легкозасвоюваному стані. Цей продукт $\epsilon$ незамінним для дитячого організму [1]. На сучасному етапі розвитку агропромислового комплексу в нашій державі проблема щодо якості молока набуває важливого значення, а ii вирішення стає загальнодержавним завданням [2]. За скрутних соціально-економічних умов гостро постало питання підвищення якості молока та молочної продукції, що мало б знайти підтримку у відповідних державних регулюючих органах, адже вступ України до СОТ обумовив жорсткі умови реалізації молока та молочної сировини [3-6].

Аналіз останніх досліджень i публікацій, у яких започатковано розв'язання проблеми. Згідно $з$ літературними даними, проблему якості молока необхідно розглядати комплексно. Під поняттям якість молока необхідно розуміти такі показники, як його склад, властивості, харчову цінність та засвоюваність, наявність у ньому небажаних та сторонніх речовин та включень, які можуть потрапляти до нього ззовні $[7,8]$.
Багато в чому якість молока безперечно залежить від умов його отримання та зберігання. Нині все більше спостерігається тенденція до появи в молоці невластивих йому компонентів. Так, у ньому виявляють наступні невластиві речовини та їх залишки: лікарські препарати, мінеральні та органічні добрива, засоби боротьби із сільськогосподарськими шкідниками, засоби для дезінфекції, дезінсекції та дезінвазії, які використовуються в тваринництві, а також миючі та дезінфікуючі засоби для доїльних апаратів і обладнання [9]. Всі ці непритаманні для молока сполуки та речовини потрапляють до нього безпосередньо з організму тварин, яким їх використовували, або ж з навколишнього середовища через корми та воду. Звичайно, інколи до появи «зайвих компонентів молока» призводить сама тара або ж посуд, в якому молоко зберігалося чи транспортувалося. Варто зауважити, що згідно 3 загальноприйнятими правилами та нормами для молока, недопустимими вважаються наступні компоненти: афлатоксини, антибіотики, пестициди, лікарські та миючі засоби тощо [10, 11].

У зв'язку з цим метою роботи було провести аналіз звітної документації державних лабораторій ветеринарної медицини у Полтавській області за 2012-2016 рр. щодо якості та безпечності молока.

У завдання досліджень входило встановити кількість проведених досліджень молока, визначити відсоток вибраковки продукту, виявити причини, за якими проводили вибраковку молока.

Матеріали і методи досліджень. Дослідження оцінки якості та безпечності молока проводили за результатами аналізу звітної документації державних лабораторій ветеринарної медицини у Полтавській області за період з 2012 по 2016 р.

Визначали кількість проведених експертиз за кожний рік та за п'ять років. Встановлювали кількість та відсоток вибракованих проб молока та основні показники, за якими молоко не відповідало нормативним стандартам. 


\section{ВЕТЕРИНАРНА МЕДИЦИНА}

Результати досліджень. Вивчення та аналіз звітної документації (період 2012-2016 рр.) показало, що державні лабораторії ветеринарної медицини у Полтавській області проводять значну роботу щодо недопущення до реалізації недоброякісного та шкідливого молока.

Встановлено, що впродовж 2012-2016 pp. на території Полтавської області загалом було проведено 740190 експертиз проб молока (табл. 1), 3 яких: 117361 здійснено у 2012 році, 142006 - у 2013 році, 80380 - у 2014 році, 203704 - у 2015 році та 196739 - у 2016 році. Загалом було виявлено 8343 зразки молока, що не відповідали діючим стандартам.

Згідно $з$ даними звітної документації, за вказаний період спостерігається позитивна тенденція до зменшення відсотку вибракування молока за причини його невідповідності. Так, у 2012 р. державними лабораторіями ветеринарної медицини Полтавської області було виявлено 3327 невідповідних зразків молока, що становило $2,83 \%$ від загальної кількості досліджуваних зразків. У 2013 р. цей показник був дещо мен- шим та становив 2248 зразків (1,58 \%). У 2014 та 2015 рр. спостерігали таку ж тенденцію, кількість невідповідних зразків молока становила відповідно 1080 та 925 (1,34 та 0,45\%). Найменшу кількість невідповідних проб молока на території Полтавської області було виявлено у 2016 році. Так, з 196739 досліджуваних зразків молока кількість невідповідних становила 763 $(0,39 \%)$.

Таким чином, ситуація щодо якості та безпечності молока, яке реалізується на території Полтавської області з кожним роком покращується, адже в цілому за опрацьований період кількість проб невідповідного за різними показниками молока значною мірою зменшилася (з 2,83 до $0,39 \%)$.

Під час вивчення причин вибраковки молока встановлено, що у більшості випадків якість продукту не відповідала діючим стандартам за густиною, кислотністю, вмістом та масовою часткою білку i жиру, а також за перевищенням кількості соматичних клітин (табл. 2).

\section{1. Обсяг проведених досліджень молока державними лабораторіями ветеринарної медицини на території Полтавської області}

\begin{tabular}{|c|c|c|c|}
\hline \multirow{2}{*}{ Рік дослідження } & Кількість проведених & \multicolumn{2}{|c|}{ Кількість невідповідних проб продукції } \\
\cline { 3 - 4 } & випробувань, шт. & шт. & $\%$ \\
\hline 2012 & 117361 & 3327 & 2,83 \\
\hline 2013 & 142006 & 2248 & 1,58 \\
\hline 2014 & 80380 & 1080 & 1,34 \\
\hline 2015 & 203704 & 925 & 0,45 \\
\hline 2016 & 196739 & 763 & 0,39 \\
\hline Усього за 5 років & 740190 & 8343 & 1,13 \\
\hline
\end{tabular}

2. Показники невідповідності молока, яке реалізується на території Полтавської області

\begin{tabular}{|l|c|c|c|c|c|}
\hline \multirow{2}{*}{ Показники невідповідності } & \multicolumn{5}{|c|}{ Роки дослідження } \\
\cline { 2 - 6 } & 2012 & 2013 & 2014 & 2015 & 2016 \\
\hline $\begin{array}{l}\text { Загальна кількість невідповідних зразків, } \\
\text { у т. ч. (\%), за: }\end{array}$ & 3327 & 2248 & 1080 & 925 & 763 \\
\hline - органолептичними показниками & - & & 0,46 & 0,97 & - \\
\hline - густиною & 11,03 & 11,38 & 20,55 & 16,84 & 24,52 \\
\hline - кислотністю & 1,65 & 0,04 & 0,83 & 9,84 & - \\
\hline - вмістом / масовою часткою білку & $9,07 / 35,65$ & $-/ 15,70$ & $30,65 /-$ & $-/ 33,73$ & $-/$ \\
\hline - масовою часткою жиру & 25,31 & 17,92 & 35,37 & 17,01 & 24,74 \\
\hline - наявністю інгібуючих речовин & 0,12 & - & 0,30 & 0,97 & 0,52 \\
\hline - наявністю соматичних клітин & 8,54 & 0,89 & 7,77 & 13,40 & 10,35 \\
\hline - чистотою & 1,12 & 1,38 & 0,55 & - & 0,65 \\
\hline - сухим знежиреним молочним залишком & 7,06 & 1,47 & - & - & - \\
\hline - вмістом води / фальсифікація & $0,45 /-$ & - & $3,52 /-$ & $-/ 4,86$ & $-/ 4,19$ \\
\hline - інші & - & 49,86 & - & 2,38 & 4,81 \\
\hline
\end{tabular}




\section{ВЕТЕРИНАРНА МЕДИЦИНА}

Значно рідше причинами вибракування були вади, виявлені в результаті органолептичних досліджень, а також невідповідність за чистотою молока та сухого знежиреного молочного залишку. До таких причин варто також віднести наявність у продукті інгібуючих речовин та води, фальсифікацію та інші.

За наслідками вивчення причин, які призвели до невідповідності молока у 2012 році встановлено, що у більшості випадків (від 7,06 до 35,65 \%) встановлювали погіршення якості молока за сухим знежиреним молочним залишком, кількістю соматичних клітин, вмістом білка, густиною та масовою часткою білку в продукті. Меншою мірою (до 5,0 \%) невідповідність виявляли в результаті наявності у молоці інгібуючих речовин та води, а також зниження ступеню чистоти та підвищення кислотності. У 2013 р. серед основних причин, які призводили до вибракування молока були: невідповідність 3 боку масової частки жиру та білку $(17,92-15,70$ \% відповідно), густини $(11,38 \%)$ та інші причини (49,86 \%). У решті випадків (до $5 \%$ ) невідповідність була виявлена за показниками кислотності, кількості соматичних клітин, чистоти та сухого знежиреного молочного залишку.

У 2014 та 2015 роках серед основних причин вибраковки молока були невідповідність за показниками густини (20,55 та 16,84 \% відповідно) та вмісту і масової частки білку (30,65 та 33,73 \% відповідно), масової частки жиру $(35,37$ та $17,01 \%$ відповідно), кількості соматичних клітин (7,77 та 13,40\% відповідно), а також кислотності молока у 2014 році $(9,84 \%)$. Меншою мірою (до $10 \%$ ) причинами невідповідності молока були: наявністю інгібуючих речовин, вади по органолептичним показникам, вміст води, фальсифікація, кислотність, чистота молока тощо.

\section{БІБЛІОГРАФІЯ}

1. Ветеринарно-санітарна експертиза 3 основами технології і стандартизації продуктів тваринництва / [Якубчак О. М., Хоменко В. І., Мельничук С. Д. та ін.] ; за ред. О. М. Якубчак, В. І. Хоменко. - К., 2005. - $800 \mathrm{c}$.

2. Ліпич Л. Г. Якість молочної сировини в Україні: перспективи підвищення / Л. Г. Ліпич, А. М. Момчева // Інноваційна економіка. - 2010. - №6. - C. 152-157.

3. Про основні принципи та вимоги до безпечності та якості харчових продуктів: закон України від 23.12.1997 № 771/97-ВР (в ред. від 20.09.2015) // Офіційний вісник України. - 1998. - №3. - Ст. 75.

4. Регулювання продовольчої безпеки в зако-
Найменше вибракувано молока у 2016 році. Основними причинами цього були: висока кількість соматичних клітин $(10,35 \%)$, невідповідність 3 боку густини та масової частки жиру (24,52 та 24,74 \% відповідно), а також у масовій частці білку (30,22\%). У меншій кількості (менше $5 \%$ ) виявляли невідповідність молока за показниками наявності інгібуючих речовин та чистоти тощо.

Таким чином встановлено, що найчастіше зниження якості та безпечності молока, яке реалізується на території Полтавської області, відбувається внаслідок невідповідності діючим стандартам показників густини і кислотності молока, вмісту і масової частки білка та жиру, а також перевищення кількості соматичних клітин.

\section{Висновки:}

1. Встановлено, що впродовж 2012-2016 pp. на території Полтавської області проведено 740190 експертиз молока, 3 яких 8343 виявилися невідповідними щодо діючих стандартів якості та безпечності продукту, що призводило до його недопущення в реалізацію та вибракування.

2. Найбільший відсоток неякісного молока виявлено у 2012 та 2013 роках (2,83-11,58 \% відповідно).

3. Основними причинами, що призводять до недопущення молока в реалізацію та подальшого його вибракування на території Полтавської області була невідповідність за густиною, кислотністю, вмістом і масовою часткою білка та жиру, а також перевищення кількості соматичних клітин.

Перспективи подальшої роботи в цьому напрямі. Перспективами подальших досліджень $\epsilon$ визначення якості та безпечності молока різних виробників, яке потрапляє на реалізацію у Полтавській області.

нодавстві Свропейського Союзу та Україні : порівняльно-правове дослідження / [Іншин М. І., Мироненко Т. Є., Клюєв О. М., Куліш А. М. та ін.] ; за ред. д. ю. н. М. І. Іншина [Електронний pecypc]. - Режим доступу http://old.minjust.gov.ua/section/168.

5. Про молоко та молочні продукти : закон України в ред. від 05.04.2015 // Офіційний вісник України. - 2004. - №30. - Ст. 1984.

6. Регламент Комиссии ЕС № 605/2010 от 2 июля 2010 года, устанавливающий условия охраны здоровья животных и людей и ветеринарной сертификации для ввоза в Европейский Союз сырого молока и молочных продуктов, предназначенных для потребления человеком 


\section{ВЕТЕРИНАРНА МЕДИЦИНА}

[Електронний ресурс]. - Режим доступу : www.fsvps.ru/fsvps-docs/ru/usefulinf/files/es6052010.pdf.

7. Правила ветеринарно-санітарної експертизи молока і молочних продуктів та вимоги щодо їх реалізації, затверджені наказом Державного департаменту ветеринарної медицини від 20.04.2004 за № 49.

8. Погребечький $B . \quad$ Ветеринарно-санітарна експертиза молока та молочних продуктів на продовольчих ринках / $\mathrm{B}$. Погребецький, С. Заєць // Ветеринарна медицина України. 2001. - №3. - C. 34-35.

9. Про затвердження Державних санітарних норм та правил «Медичні вимоги до якості та безпечності харчових продуктів та продовольчої сировини» : наказ Міністерства охорони здоров’я України від 29.12.2012 № 1140 // Офіційний вісник України. - 2013. - №6. - Ст. 227.

10. Стрига А. М. Ветеринарно-санітарна оцінка молока, що реалізується на ринках та шляхи підвищення його якості / А. М. Стрига // Аграрний вісник Причорномор'я. - Зб. наук. пр. Одеського ДАУ : Ветеринарні науки. - Вип. 42. 2008. - Ч. 1. - С. 127-130.

11. Шевага Л. В. Систематичні дослідження молока на мастити на приймальних пунктах запорука якості готової продукції / Л.В.Шевага // Ветеринарна медицина України. - 2010. - №4. - C. 36-37. 